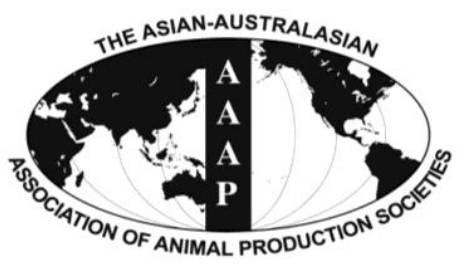

Asian-Aust. J. Anim. Sci.

Vol. 25, No. 3 : 393 - 400

March 2012

www.ajas.info

http://dx.doi.org/10.5713/ajas.2011.11381

\title{
Effects of Replacement of Soybean Meal by Fermented Cottonseed Meal on Growth Performance, Serum Biochemical Parameters and Immune Function of Yellow-feathered Broilers
}

\author{
J. W. Tang*, H. Sun ${ }^{1}$, X. H. Yao, Y. F. Wu, X. Wang and J. Feng ${ }^{1}$ \\ Institute of Plant Protection and Microbiology, Zhejiang Academy of Agriculture Sciences, \\ No. 198 Shiqiao Road, Hangzhou, 310021, China
}

\begin{abstract}
The study was conducted to examine the effects of partially replacing soybean meal (SBM) by solid-state fermented cottonseed meal (FCSM) on growth performance, serum biochemical parameters and immune function of broilers. After inoculated with Bacillus subtilis BJ-1 for $48 \mathrm{~h}$, the content of free gossypol in cottonseed meal was decreased from 0.82 to $0.21 \mathrm{~g} / \mathrm{kg}$. A total of 600 , dayold male yellow-feathered broilers were randomly divided into four groups with three replicates of 50 chicks each. A corn-SBM based control diet was formulated and the experimental diets included 4, 8 or 12\% FCSM, replacing SBM. Throughout the experiment, broilers fed $8 \%$ FCSM had higher ( $\mathrm{p}<0.05$ ) body weight gain than those fed 0,4 and $12 \%$ FCSM. The feed intake in $8 \%$ FCSM group was superior $(\mathrm{p}<0.05)$ to other treatments from $\mathrm{d} 21$ to 42 . On d 21, the concentration of serum immunoglobin $\mathrm{M}$ in the $4 \%$ and $8 \%$ FCSM groups, as well as the content of complements $(C 3, C 4)$ in $8 \%$ FCSM group were greater $(\mathrm{p}<0.05)$ than those in the SBM group. Besides, birds fed 8\% FCSM had increased ( $\mathrm{p}<0.05$ ) serum immunoglobin M, immunoglobulin $\mathrm{G}$ and complement C4 levels on d 42 compared with bird fed control diet. No differences $(p>0.05)$ were found between treatments regarding the serum biochemical parameters and the relative weights of immune organs. In conclusion, FCSM can be used in broiler diets at up to $12 \%$ of the total diet and an appropriate replacement of SBM with FCSM may improve growth performance and immunity in broilers. (Key Words : Bacillus subtilis, Fermented Cottonseed Meal, Growth Performance, Immune Function, Serum Parameters, Yellow-feathered Broiler)
\end{abstract}

\section{INTRODUCTION}

Soybean meal (SBM) is recognized as an effective protein source in the formulation of poultry diets. However, the cost of SBM has been increased in recent years, urging poultry producers to seek alternative sources that are more economical to use. Cottonseed meal (CSM) is a byproduct of the process of extracting the oil from cotton seeds and has long been considered as an alternative to SBM in China.

The use of CSM as a protein supplement in poultry diets is limited due to the presence of gossypol and a relative low lysine level compared to SBM. Studies have found that free gossypol could depress growth performance and increase mortality in broilers (Henry et al., 2001). Factors such as nutrient density (Watkins and Waldroup, 1995; Sterling et

\footnotetext{
* Corresponding Author: J. W. Tang. Tel : +86-571-8640-4323, Fax : +86-571-8640-4323, E-mail : tangjiangwu@ sina.com.cn

${ }^{1}$ College of Animal Sciences, Zhejiang University, No. 388, Yuhangtang Road, Hangzhou, 310058, China.

Submitted Oct. 21, 2011; Accepted Dec. 6, 2011; Revised Dec. 27, 2011
}

al., 2002) and lysine level (Watkins et al., 1994; Azman and Yilmaz, 2005) may alleviate the negative effects of gossypol. Other findings have demonstrated that broiler performance may not significantly be affected when the content of dietary free gossypol is lower than $200 \mathrm{mg} / \mathrm{kg}$ of feed (Hermes et al., 1983). Therefore, the inclusion of CSM in broiler diets still largely depends on the content of free gossypol in CSM.

Solid-state fermentation has been recently reported as a effective way to reduce free gossypol and improve amino acid content of CSM (Weng and Sun, 2006; Zhang et al., 2006a; Zhang et al., 2007). Moreover, the fermentation process produces varieties of essential nutrients such as vitamins, oligosaccharides and small-size peptides which may further increase the nutritional value of CSM (Kim et al., 1999; Feng et al., 2007b; Chen et al., 2010), extending the use of CSM in poultry industry. Recently, the microorganisms used for CSM fermentation has been focused on fungi (Zhang et al., 2007). Bacillus subtilis is recognized as a safe strain for solid-state fermentation in 
both food and feed industry (Kim et al., 2005). Recent study has shown that fermentation by $B$. subtilis can improve the in vivo digestbility of SBM in piglets (Feng et al., 2007b). However, the effects of fermentation by $B$. subtilis on CSM and the animal evaluation of fermented cottonseed meal (FCSM) are scarce.

Yellow-feathered broiler is one of valuable commercial chicken species in China with its production approaching 3 billion every year. The objective of the present study is to evaluate whether fermentation of CSM by B. subtilis could improve its nutritional values. Then, studies were conducted to determine the effects of FCSM on growth performance, serum biochemical parameters and immune function in yellow-feather broilers, replacing SBM with FCSM at graded levels in $4 \%$ increments.

\section{MATERIALS AND METHODS}

\section{Preparation of solid-state FCSM}

The strain of B. subtilus BJ-1 and the CSM were obtained from Zhejiang Academy of Agricultural Sciences (ZAAS, Zhejiang, China). The B. subtilus BJ-1 (China General Microbiological Culture Collection, number 2288) was isolated from garden soil and has been used for fermentation of feed materials in our lab for more than 5 years and no known harmful effects on broilers and pigs. For the fermentation of CSM, B. subtilus BJ-1 was first cultured by Luria-Bertani (LB) agar (Oxoid, Hampshire, England) at $30^{\circ} \mathrm{C}$ for $24 \mathrm{~h}$ and then the inoculum (one loop) was transferred into 300-ml flasks containing $50 \mathrm{ml}$ of LB broth at $30^{\circ} \mathrm{C}$ for $48 \mathrm{~h}$. The number of $B$. subtilus BJ-1 was determined using dilution-plate method on LB agar to be about $1.4 \times 10^{8} \mathrm{cfu} / \mathrm{ml}$ according to Grigorova and Norris (1990).

The fermentation of CSM was taken by soaking the CSM with water in a ratio 1:1 (one part CSM to one part water) and then inoculated with $1 \%$ B. subtilus BJ-1 culture (vol/wt, $\pm 10^{6} \mathrm{cfu}$ per gram of CSM), mixed and fermented in a plastic container $(20 \mathrm{~cm} \times 20 \mathrm{~cm} \times 30 \mathrm{~cm})$ for $48 \mathrm{~h}$ at $30^{\circ} \mathrm{C}$. After fermentation, the CSM samples were dried at $50^{\circ} \mathrm{C}$ to $60^{\circ} \mathrm{C}$ in an oven for $1 \mathrm{~d}$ to about $90 \%$ dry matter. The dried samples were subsequently milled fitted with 1 $\mathrm{mm}$ mesh screen and stored at room temperature.

\section{Broiler husbandry and experimental design}

The experiment was carried out in accordance with the Chinese Guidelines for Animal Welfare (1988) and the procedures were supervised by the Animal Care and Use Committee of Zhejiang Academy of Agriculture Sciences. Six-hundred 1-d-old male yellow-feathered broiler chickens (slow-growing breed) weighing an average of $41.87 \pm 0.23 \mathrm{~g}$ were divided randomly into 4 groups, each consisting of 3 replicates of 50 chickens. The feeding program consisted of two feeds for starter phase ( 0 to $3 \mathrm{wk}$ ) and finisher phase (4 to $6 \mathrm{wk})$, respectively. The control birds were fed a cornSBM based diet according to Nutrient Requirements of Poultry (NRC, 1994) and Nutrient Requirements of Yellowfeathered Broiler (NY/T 33-2004, China). The three treatment groups were fed with a similar diet in which the SBM was partly replaced by 4,8 , or $12 \%$ FCSM (Table 1 ). The experimental diets were provided in mash form $(5 \mathrm{~mm}$ screen).

The chicks were caged in solid-floored pens $(3.2 \mathrm{~m}$ $\times 3.2 \mathrm{~m} \times 0.9 \mathrm{~m})$ and raised in a temperature and humidity controlled room with a 24 -h constant light schedule and $a d$ libitum access to water and feed throughout the experiment. Birds were weighted by pen and feed consumption was recorded weekly. Body weight gain (BWG), feed intake (FI) and feed conversion ratio $(\mathrm{FCR})$ was calculated $(\mathrm{FCR}=\mathrm{FI}$ : $\mathrm{BWG}$ ). The experiment was constructed as a randomized complete block design with a pen as a unit of experiment.

\section{Sampling procedure and analytical methods}

At the end of the two feeding phases (d 21 and d 42), twelve birds per replicate were slaughtered and blood samples were collected in heparinized tubes from the wing vein of the broilers and centrifuged at $2,500 \times \mathrm{g}$ for $15 \mathrm{~min}$ at $4^{\circ} \mathrm{C}$. Serum samples were then isolated and stored at $-20^{\circ} \mathrm{C}$ until use for analysis of biochemical parameters (Mountzouris et al., 2010). Serum biochemical parameters were evaluated for total protein (TP), albumin (Alb), total phosphate $(\mathrm{P})$ and calcium $(\mathrm{Ca})$ content using clinical chemistry reagents (Randox, Crumlin, England) and an automatic clinical chemistry analyser (Randox Daytona, Crumlin, England).

Immunoglobulin A ( $\operatorname{IgA})$, Immunoglobulin $\mathrm{M}$ ( $\operatorname{IgM})$ and Immunoglobulin $\mathrm{G}$ ( $\mathrm{IgG}$ ) levels in serum were detected based on the immunoturbidimetry method as described by Feng et al. (2007a). Complements (C3 and C4) concentrations in sera were determined by using an indirect enzyme-linked immunosorbent assay as described by Feng et al. (2009).

Additionally, the spleen, thymus and bursa of fabricus of these chickens were removed and weighed. Organ weights were calculated relative to the chicken's body weight.

\section{Chemical analysis}

The dry matter (DM) content of SBM, CSM and FCSM was analyzed by drying the samples at $105^{\circ} \mathrm{C}$ for $5 \mathrm{~h}$, Ash by incineration at $550^{\circ} \mathrm{C}$ for $24 \mathrm{~h}$ in a muffle furnace, crude protein $(\mathrm{CP})$ by a kjeldahl method multiplying by a factor of 6.25 (AOAC, 1999; method 988.05) and fat content was measured by extracting the oil with diethyl ether according to Wang et al. (2004), pre-treating with $4 \mathrm{~mol} / \mathrm{L} \mathrm{HCl}$ to ensure the complete recovery of fat. Free gossypol contents 
Table 1. Ingredient composition of diets used to determine the effects of graded levels of fermented cottonseed meal on the performance of yellow-feathered broilers ( $\%$ as fed basis unless otherwise stated)

\begin{tabular}{|c|c|c|c|c|c|c|c|c|}
\hline \multirow[b]{2}{*}{ Items } & \multicolumn{4}{|c|}{ Starter phase (d 1 to 21 ) } & \multicolumn{4}{|c|}{ Finisher phase (d 22 to 42 ) } \\
\hline & $\mathrm{SBM}^{1}$ & $\begin{array}{c}4 \% \\
\text { FCSM }^{2}\end{array}$ & $\begin{array}{c}8 \% \\
\text { FCSM }\end{array}$ & $\begin{array}{c}12 \% \\
\text { FCSM }\end{array}$ & SBM & $\begin{array}{c}4 \% \\
\text { FCSM }\end{array}$ & $\begin{array}{c}8 \% \\
\text { FCSM }\end{array}$ & $\begin{array}{c}12 \% \\
\text { FCSM }\end{array}$ \\
\hline \multicolumn{9}{|l|}{ Ingredients } \\
\hline Corn & 55.00 & 55.00 & 55.00 & 55.00 & 63.00 & 63.00 & 63.00 & 63.00 \\
\hline Soybean meal $(47 \% \mathrm{CP})$ & 25.00 & 21.00 & 17.00 & 13.00 & 18.00 & 14.00 & 10.00 & 6.00 \\
\hline Cottonseed meal $(46.5 \% \mathrm{CP})$ & 1.50 & 1.50 & 1.50 & 1.50 & 1.50 & 1.50 & 1.50 & 1.50 \\
\hline Fermented cottonseed meal $(50.5 \% \mathrm{CP})$ & 0 & 4.00 & 8.00 & 12.00 & 0 & 4.00 & 8.00 & 12.00 \\
\hline Wheat middlings & 2.00 & 2.00 & 2.00 & 2.00 & 2.00 & 2.00 & 2.00 & 2.00 \\
\hline Corn gluten meal (63\% CP) & 8.00 & 8.00 & 8.00 & 8.00 & 8.00 & 8.00 & 8.00 & 8.00 \\
\hline Dicalcium phosphate & 1.50 & 1.50 & 1.50 & 1.50 & 1.50 & 1.50 & 1.50 & 1.50 \\
\hline Soybean oil & 3.50 & 3.50 & 3.50 & 3.50 & 3.00 & 3.00 & 3.00 & 3.00 \\
\hline Limestone & 2.00 & 2.00 & 2.00 & 2.00 & 1.50 & 1.50 & 1.50 & 1.50 \\
\hline DL-methionine (98\%) & 0.20 & 0.20 & 0.20 & 0.20 & 0.10 & 0.10 & 0.10 & 0.10 \\
\hline L-lysine $\mathrm{HCl}(78 \%)$ & 0.30 & 0.30 & 0.30 & 0.30 & 0.40 & 0.40 & 0.40 & 0.40 \\
\hline Sodium chloride & 0.40 & 0.40 & 0.40 & 0.40 & 0.40 & 0.40 & 0.40 & 0.40 \\
\hline Vitamin-mineral premix ${ }^{3}$ & 0.60 & 0.60 & 0.60 & 0.60 & 0.60 & 0.60 & 0.60 & 0.60 \\
\hline \multicolumn{9}{|l|}{ Nutrient content ${ }^{4}$} \\
\hline ME (Mcal/kg) & 3.10 & 3.10 & 3.10 & 3.10 & 3.20 & 3.20 & 3.20 & 3.20 \\
\hline Crude protein & 23.00 & 23.11 & 23.17 & 23.20 & 20.45 & 20.58 & 20.61 & 20.71 \\
\hline Ether extract & 6.05 & 6.01 & 5.99 & 5.98 & 5.69 & 5.67 & 5.65 & 5.64 \\
\hline Fiber & 2.47 & 2.53 & 2.62 & 2.71 & 2.13 & 2.24 & 2.31 & 2.43 \\
\hline Lysine & 1.23 & 1.21 & 1.19 & 1.17 & 1.12 & 1.15 & 1.19 & 1.21 \\
\hline Methionine & 0.62 & 0.59 & 0.59 & 0.59 & 0.48 & 0.46 & 0.46 & 0.46 \\
\hline Threonine & 0.82 & 0.82 & 0.82 & 0.81 & 0.72 & 0.73 & 0.71 & 0.71 \\
\hline Arginine & 1.31 & 1.36 & 1.40 & 1.43 & 1.10 & 1.10 & 1.08 & 1.07 \\
\hline Total sulfur amino acids & 1.06 & 1.02 & 1.04 & 1.02 & 0.73 & 0.73 & 0.73 & 0.73 \\
\hline Calcium & 1.08 & 1.08 & 1.08 & 1.08 & 0.89 & 0.89 & 0.89 & 0.89 \\
\hline Total phosphorus & 0.68 & 0.70 & 0.72 & 0.74 & 0.67 & 0.69 & 0.71 & 0.73 \\
\hline
\end{tabular}

${ }^{1} \mathrm{SBM}=$ Soybean meal. ${ }^{2}$ FCSM $=$ Fermented cottonseed meal.

${ }^{3}$ Provided per kilogram of diet: vitamin $\mathrm{A}, 15,000 \mathrm{IU}$; vitamin $\mathrm{D}_{3}, 4,500 \mathrm{IU}$; vitamin E, $30 \mathrm{mg}$; vitamin $\mathrm{K}_{3}, 4 \mathrm{mg}$; vitamin $\mathrm{B}_{1}, 5 \mathrm{mg}$; vitamin $\mathrm{B}_{2}, 10 \mathrm{mg}$; vitamin $\mathrm{B}_{6}, 5 \mathrm{mg}$; vitamin $\mathrm{B}_{12}, 0.02 \mathrm{mg}$; niacin, $45.5 \mathrm{mg}$; pantothenic acid, $20.5 \mathrm{mg}$; biotin, $0.45 \mathrm{mg}$; copper, $8 \mathrm{mg}$; iron, $80 \mathrm{mg}$; manganese, $60 \mathrm{mg}$; zinc, $40 \mathrm{mg}$; selenium, $0.3 \mathrm{mg}$; iodine, $0.35 \mathrm{mg}$.

${ }^{4}$ Analytical values, for all variables $(n=3)$ except for ME that were calculated.

of CSM and FCSM were determined according to the method of the American Oil Chemists Society (AOCS, 2009; method $\mathrm{Ba}$ 7b-96). The crude fiber content was determined by the filter bag technique after digesting with $\mathrm{H}_{2} \mathrm{SO}_{4}$ and $\mathrm{NaOH}$ (AOCS, 2009; method Ba 6a-05). Amino acid assay was based on the AOAC (1999) method number 994.12. Phosphorus (Method Ca 12b-92) and Calcium (Method Ca 15b-87) were assayed as described by AOCS (2009). All analyses except amino acids were performed in triplicates.

\section{Statistical analysis}

Data were analyzed by one-way ANOVA using the General Linear Models Procedure in SAS (SAS, 1998). Pen was used as the experimental unit and the results are expressed as means and calculated for linear and quadratic effects of graded levels of FCSM added. Significant effects were further analyzed and individual mean differences were determined by Duncan's multiple-range test. A significance level of 0.05 was used.

\section{RESULTS}

\section{Chemical composition of FCSM}

CSM fermented by B. subtilis BJ-1 had higher levels of nutrient compositions as well as amino acid profiles except for contents of ether extract ( $10.0 \mathrm{~g} / \mathrm{kg}$ vs. $10.8 \mathrm{~g} / \mathrm{kg})$, crude fiber $(90.3 \mathrm{~g} / \mathrm{kg}$ vs. $102.1 \mathrm{~g} / \mathrm{kg})$ and arginine $(47.2 \mathrm{~g} / \mathrm{kg}$ vs. $49.8 \mathrm{~g} / \mathrm{kg}$ ) than CSM (Table 2). Furthermore, fermentation of the CSM dramatically decreased free gossypol content by $74.39 \%$ in comparison with CSM (from $0.82 \mathrm{mg} / \mathrm{kg}$ to 0.21 $\mathrm{mg} / \mathrm{kg}$ ). Comparatively, FCSM contained higher levels of 
Table 2. Chemical composition of the soybean meal, cottonseed meal and fermented cottonseed meal used ( $\mathrm{g} / \mathrm{kg}$, as fed basis) ${ }^{1}$

\begin{tabular}{lccc}
\hline Component & $\mathrm{SBM}^{2}$ & $\mathrm{CSM}^{3}$ & FCSM $^{4}$ \\
\hline Crude protein & 470.1 & 465.2 & 505.1 \\
Ether extract & 15.1 & 10.8 & 10.0 \\
Ash & 54.3 & 60.2 & 65.3 \\
Crude fiber & 62.1 & 102.1 & 90.3 \\
Dry matter & 879.1 & 882.3 & 891.4 \\
Amino acids & & & \\
$\quad$ Lysine & 29.2 & 21.3 & 24.2 \\
Methionine & 6.50 & 5.60 & 6.10 \\
Cystine & 7.30 & 6.40 & 7.90 \\
Methionine+cystine & 1.40 & 1.20 & 1.40 \\
Threonine & 18.2 & 14.5 & 17.4 \\
Arginine & 34.3 & 49.8 & 47.2 \\
Isoleucine & 21.1 & 15.2 & 16.9 \\
Leucine & 35.2 & 26.8 & 34.1 \\
Valine & 22.6 & 21.5 & 23.4 \\
Histidine & 12.1 & 12.6 & 14.4 \\
Phenylalanine & 23.3 & 24.3 & 29.5 \\
Total phosphorus & 5.60 & 11.1 & 13.1 \\
Calcium & 2.70 & 2.50 & 2.60 \\
Free gossypol & $\mathrm{ND}^{5}$ & 0.82 & 0.21 \\
\hline TAn & & &
\end{tabular}

${ }^{1}$ Analytical values, means of triplicate analyses.

${ }^{2} \mathrm{SBM}=$ Soybean meal. ${ }^{3} \mathrm{CSM}=$ Cottonseed meal.

${ }^{4} \mathrm{FCSM}=$ Fermented cottonseed meal. ${ }^{5} \mathrm{ND}=$ Not detected.

ash $(65.3 \mathrm{~g} / \mathrm{kg}$ vs. $54.3 \mathrm{~g} / \mathrm{kg})$, crude fiber $(90.3 \mathrm{~g} / \mathrm{kg}$ vs. 62.1 $\mathrm{g} / \mathrm{kg}$ ) and crude protein $(505.1 \mathrm{~g} / \mathrm{kg}$ vs. $470.1 \mathrm{~g} / \mathrm{kg}$ ) than SBM (Table 2). In contrast, FCSM had lower levels of lysine, methionine, threonine, leucine, isoleucine and calcium than that of the SBM. The free gossypol content in SBM was not detected for it is not considered as antinutritive factors.

\section{Growth performance of broiler}

Birds initial BW did not differ between treatments at the start of the experimental period (Table 3). Mortality of birds in each treatment was lower than $4 \%$ throughout the experimental period (Table 3). Broilers fed 8\% FCSM had higher $(\mathrm{p}<0.05)$ BWG than birds fed 0, 4 or $12 \%$ FCSM diets at both 3 and 6 weeks of age (Table 3). From 22 to 42 $\mathrm{d}$, broilers fed $8 \%$ FCSM had higher $(\mathrm{p}<0.05)$ FI compared with birds fed SBM. Over the entire 42-d growth trial, the BWG of birds fed $8 \%$ FCSM was superior $(\mathrm{p}<0.01)$ to those of birds fed 0,4 or $12 \%$ FCSM diets. There were no significant differences in FCR between treatments in both starter and finisher phases as well as for the whole experiment.

\section{Serum biochemistry parameters}

In both growth phases, there were no changes ( $p>0.05)$ between treatments regarding the concentrations of TP, Alb, P, Ca (Table 4).

\section{Serum immunoglublins and complements}

At $21 \mathrm{~d}$ of age, the concentration of IgM of birds fed $8 \%$ FCSM was higher $(p<0.01)$ compared with those of birds fed SBM and $12 \%$ FCSM but did not differ from the $4 \%$ FCSM group (Table 4). Similarly, birds fed $8 \%$ FCSM had increased $(\mathrm{p}<0.05)$ serum concentrations of $\operatorname{IgM}$ and $\operatorname{IgG}$ at $42 \mathrm{~d}$ of age compared with birds fed SBM and $12 \%$ FCSM.

Table 3. Growth performance of yellow-feathered broilers fed diets containing 0, 4, 8 and $12 \%$ of Bacillus subtilis fermented cottonseed meal from 0 to 42 days of age ${ }^{1}$

\begin{tabular}{|c|c|c|c|c|c|c|c|}
\hline \multirow{2}{*}{ Items } & \multicolumn{4}{|c|}{ Fermented cottonseed meal levels (\%) } & \multirow{2}{*}{$\mathrm{SEM}^{3}$} & \multicolumn{2}{|c|}{ p-values } \\
\hline & 0 & 4 & 8 & 12 & & Linear & Quadratic \\
\hline Initial BW (g) & 41.9 & 41.6 & 41.9 & 42.1 & 0.21 & & \\
\hline Mortality rate $(\%)$ & 3.06 & 3.23 & 2.23 & 2.50 & 0.22 & 0.217 & 0.914 \\
\hline \multicolumn{8}{|l|}{ Day 1 to 21} \\
\hline Body weight gain (g) & $511^{\mathrm{b}}$ & $512^{\mathrm{b}}$ & $519^{\mathrm{a}}$ & $507^{\mathrm{b}}$ & 1.6 & 0.02 & $<0.001$ \\
\hline Feed intake $(\mathrm{g})$ & 827 & 826 & 817 & 815 & 7.5 & 0.52 & 0.98 \\
\hline Feed conversion ratio ${ }^{2}$ & 1.62 & 1.61 & 1.58 & 1.63 & 0.016 & 0.97 & 0.42 \\
\hline \multicolumn{8}{|l|}{ Day 22 to 42} \\
\hline Body weight gain (g) & $1,108^{b c}$ & $1,123^{\mathrm{b}}$ & $1,154^{\mathrm{a}}$ & $1,102^{\mathrm{c}}$ & 5.3 & $<0.001$ & 0.003 \\
\hline Feed intake $(\mathrm{g})$ & $2,389^{\mathrm{b}}$ & $2,443^{\mathrm{ab}}$ & $2,509^{\mathrm{a}}$ & $2,481^{\mathrm{ab}}$ & 18.3 & 0.03 & 0.22 \\
\hline Feed conversion ratio & 2.16 & 2.18 & 2.17 & 2.21 & 0.013 & 0.22 & 0.78 \\
\hline \multicolumn{8}{|l|}{ Day 1 to 42} \\
\hline Body weight gain (g) & $1,619^{b c}$ & $1,635^{\mathrm{b}}$ & $1,674^{\mathrm{a}}$ & $1,602^{\mathrm{c}}$ & 6.5 & $<0.001$ & $<0.001$ \\
\hline Feed intake $(\mathrm{g})$ & 3,217 & 3,269 & 3,326 & 3,245 & 17.6 & 0.11 & 0.35 \\
\hline Feed conversion ratio & 1.99 & 1.99 & 1.99 & 2.03 & 0.009 & 0.21 & 0.46 \\
\hline
\end{tabular}

${ }^{1}$ Data represent means from 3 replicates (pens) per treatment, each pen included 50 birds.

${ }^{2}$ Feed conversion ratio $=$ Feed intake:body weight gain. ${ }^{3} \mathrm{SEM}=$ Standard error of the mean.

${ }^{a-c}$ Means in the same column with no common superscripts differ significantly $(p<0.05)$. 
Table 4. Serum characteristics of yellow-feathered broilers fed diets containing $0,4,8$ and $12 \%$ of Bacillus subtilis fermented cottonseed meal from 0 to 42 days of age ${ }^{1}$

\begin{tabular}{|c|c|c|c|c|c|c|c|}
\hline \multirow{2}{*}{ Items } & \multicolumn{4}{|c|}{ Fermented cottonseed meal levels (\%) } & \multirow{2}{*}{$\mathrm{SEM}^{2}$} & \multicolumn{2}{|c|}{ p-values } \\
\hline & 0 & 4 & 8 & 12 & & Linear & Quadratic \\
\hline \multicolumn{8}{|l|}{ Day 1 to 21} \\
\hline Total protein $(\mathrm{g} / \mathrm{L})$ & 413 & 426 & 396 & 394 & 18.8 & 0.77 & 0.91 \\
\hline Albumin (g/L) & 249 & 250 & 245 & 247 & 4.2 & 0.34 & 0.76 \\
\hline Calcium (mmol/L) & 2.55 & 2.59 & 2.49 & 2.66 & 0.291 & 0.72 & 0.67 \\
\hline Total phosphorus (mmol/L) & 2.24 & 2.04 & 2.11 & 2.06 & 0.216 & 0.68 & 0.96 \\
\hline Immunoglobulin M (g/L) & $0.11^{\mathrm{b}}$ & $0.19^{\mathrm{a}}$ & $0.22^{\mathrm{a}}$ & $0.11^{\mathrm{b}}$ & 0.014 & $<0.001$ & $<0.001$ \\
\hline Immunoglobulin G (g/L) & 0.28 & 0.29 & 0.28 & 0.24 & 0.017 & 0.47 & 0.56 \\
\hline Immunoglobulin A (g/L) & 0.11 & 0.10 & 0.11 & 0.10 & 0.009 & 0.96 & 0.94 \\
\hline Complement C3 (g/L) & $0.043^{\mathrm{b}}$ & $0.058^{\mathrm{ab}}$ & $0.073^{\mathrm{a}}$ & $0.062^{\mathrm{ab}}$ & 0.004 & 0.05 & 0.08 \\
\hline Complement C4 (g/L) & $0.057^{\mathrm{b}}$ & $0.063^{\mathrm{b}}$ & $0.077^{\mathrm{a}}$ & $0.062^{\mathrm{b}}$ & 0.002 & 0.06 & 0.01 \\
\hline \multicolumn{8}{|l|}{ Day 22 to 42} \\
\hline Total protein $(\mathrm{g} / \mathrm{L})$ & 445 & 460 & 441 & 432 & 5.0 & 0.14 & 0.27 \\
\hline Albumin $(\mathrm{g} / \mathrm{L})$ & 243 & 248 & 252 & 249 & 1.7 & 0.24 & 0.26 \\
\hline Calcium (mmol/L) & 2.31 & 2.47 & 2.55 & 2.46 & 0.067 & 0.45 & 0.41 \\
\hline Total phosphorus (mmol/L) & 2.02 & 2.08 & 2.14 & 2.17 & 0.090 & 0.254 & 0.222 \\
\hline Immunoglobulin M (g/L) & $0.11^{\mathrm{b}}$ & $0.14^{\mathrm{ab}}$ & $0.16^{\mathrm{a}}$ & $0.11^{\mathrm{b}}$ & 0.007 & 0.024 & 0.005 \\
\hline Immunoglobulin $\mathrm{G}(\mathrm{g} / \mathrm{L})$ & $0.24^{\mathrm{c}}$ & $0.26^{\mathrm{ab}}$ & $0.27^{\mathrm{a}}$ & $0.25^{\mathrm{bc}}$ & 0.003 & 0.224 & 0.002 \\
\hline Immunoglobulin A (g/L) & 0.15 & 0.16 & 0.16 & 0.16 & 0.003 & 0.881 & 0.855 \\
\hline Complement C3 (g/L) & 0.053 & 0.057 & 0.061 & 0.060 & 0.001 & 0.056 & 0.344 \\
\hline Complement C4 (g/L) & $0.058^{\mathrm{b}}$ & $0.066^{\mathrm{b}}$ & $0.076^{\mathrm{a}}$ & $0.065^{\mathrm{b}}$ & 0.002 & 0.054 & 0.013 \\
\hline
\end{tabular}

${ }^{1}$ Data represent means from 3 replicates (pens) per treatment, each pen included 50 birds. ${ }^{2}$ SEM $=$ Standard error of the mean.

${ }^{\mathrm{a}-\mathrm{b}}$ Means in the same column with no common superscripts differ significantly $(\mathrm{p}<0.05)$.

No significant differences were noted for the $\operatorname{IgA}$ over the entire feeding period. Moreover, the maximum serum C3 and $\mathrm{C} 4$ level $(\mathrm{p}<0.05)$ were observed in birds fed $8 \%$ FCSM at d 21, compared with those fed SBM, and 4\%, $12 \%$ FCSM (Table 4). On d 42, only serum complement C4 content in $8 \%$ FCSM group was increased $(\mathrm{p}<0.05)$.

\section{Immune organ weights}

No differences $(p>0.05)$ were found at any age for relative weights of spleen, thymus and bursa of Fabricius (Table 5).

\section{DISCUSSION}

The main findings of current study showed that FCSM had lower contents of free gossypol, ether extract, crude fiber and arginine whereas other nutrient compositions increased. Similarly, Zhang et al. (2007) reported reduced

Table 5. Relative immune organ weight of yellow-feathered broilers fed diets containing 0, 4, 8 and $12 \%$ of Bacillus subtilis fermented cottonseed meal

\begin{tabular}{|c|c|c|c|c|c|c|c|}
\hline \multirow{2}{*}{ Items } & \multicolumn{4}{|c|}{ Fermented cottonseed meal levels (\%) } & \multirow{2}{*}{$\mathrm{SEM}^{2}$} & \multicolumn{2}{|c|}{ p-values } \\
\hline & 0 & 4 & 8 & 12 & & Linear & Quadratic \\
\hline \multicolumn{8}{|l|}{ Day 1 to 21} \\
\hline Spleen $(\%)$ & 0.12 & 0.15 & 0.14 & 1.12 & 0.006 & 0.70 & 0.67 \\
\hline Thymus (\%) & 0.43 & 0.42 & 0.44 & 0.43 & 0.023 & 0.96 & 0.99 \\
\hline Bursa of fabricius (\%) & 0.32 & 0.36 & 0.33 & 0.35 & 0.014 & 0.63 & 0.74 \\
\hline \multicolumn{8}{|l|}{ Day 22 to 42} \\
\hline Spleen $(\%)$ & 0.28 & 0.32 & 0.31 & 0.28 & 0.013 & 0.98 & 0.80 \\
\hline Thymus $(\%)$ & 0.32 & 0.32 & 0.31 & 0.29 & 0.020 & 0.65 & 0.83 \\
\hline Bursa of fabricius (\%) & 0.20 & 0.21 & 0.22 & 0.20 & 0.011 & 0.77 & 0.43 \\
\hline
\end{tabular}

${ }^{1}$ Data represent means from 3 replicates (pens) per treatment, each pen included 50 birds. ${ }^{2} \mathrm{SEM}=$ Standard error of the mean. 
free gossypol content with the best detoxification ratio of 94.6\% and an increased concentration of CP using strain Candida tropicalis. The decrease in free gossypol may be attributed to the binding of proteins, or enzymes secreted by microbes that degrade free gossypol (Zhang et al., 2007). As suggested by Weng and Sun (2006) and Chiang et al. (2010), the dry matter content of CSM or rapeseed meal decreased during the solid-state fermentation because of the consumption of carbohydrate by microorganisms including B. subtilis. Thus, the increment of $\mathrm{CP}$ and other nutrients in FCSM are most likely a reflection of dry matter content decline. On the contrary, it is interesting to find contents of ether extract, crude fiber and arginine of FCSM decreased in comparison with CSM. Previous studies have reported that Bacillus strains could produce lipase (Terlabie et al., 2006) and cellulose (Amartey et al., 1999; Gessesse and Mamo, 1999) that degraded lipids and fiber into small particles. Zhang et al. (2007) also observed a reduction in the content of arginine during the process of solid-state fermentation. Therefore, the drop in ether extract, fiber and arginine may be due to the growth of $B$. subtilis BJ-1. However, the detoxification of free gossypol was lower than other reports (Weng and Sun, 2006; Zhang et al., 2006b), probably is due to the differences in microbes and substrates (CSM) used in this study, and the additional heat treatment applied in these studies but not in the curret experiment. Notably, heating CSM before fermentation can further decrease the free gossypol content (Yu et al., 1996; Zhang et al., 2007). We omitted the heating step in order to simulate the fermentation procedure under Chinese conditions. In addition, the composition of SBM used for substitution was within the range of published values for the feedstuff (NRC, 1994) which is similar to the FCSM. This indicates that the FCSM is likely to compete with SBM included in broiler diets.

The inclusion of CSM in feeds for birds has been studied for decades; however, little research has been conducted to evaluate the effects of FCSM in poultry. The results of the current study showed that up to $12 \%$ FCSM could be in corporated in the diets of yellow-feathered broilers. Previous study showed that $30 \%$ SBM could be replaced by low-gossypol CSM $(<400 \mathrm{mg} / \mathrm{kg})$ without affecting the poultry growth performance (Watkins et al., 1993). Similar findings demonstrated that CSM up to $20 \%$ or more has no negative effects on birds' performance (Gamboa et al., 2001). Interestingly, in the current research, the BWG was improved by adding $8 \%$ FCSM in the 42-d growth trial and FI was increased significantly from d 21 to d 42. In agreement with our findings, Chen et al. (2009) showed that supplementation with fermented feed produced by B. subtilis and Saccharomyces cerevisiae enhanced 21and 39-d-old BWG of broilers. $\mathrm{Xu}$ et al. (2011) also reported a significantly increased daily FI of ducks fed fermented rapeseed meal during the entire feeding period. One explanation for these results might be the improvement in CSM nutrient quality such as increase in essential amino acids digestibility and other functional nutrients such as small-size peptides and enzymes after fermentation as reported in previous studies (Kim et al., 1999; Zhang et al., 2006a). Fritts et al. (2000) demonstrated that diets supplemented with $B$. subtilis could improve broiler FCR. FCSM used in this experiment probably contains live $B$. subtilis which may in turn be contributed to its growth and FI promoting effect. In contrast, the inclusion of 4 or $12 \%$ FCSM did not show any significant changes on broilers' growth performance compared with the birds fed SBM; this suggests that the quality improvement of CSM was only one of the factors affecting the growth performance of the yellow-feathered broilers. There was also no significant difference in FCR between FCSM-fed treatments and the control group. This finding seems to be in agreement with the previous study, which has demonstrated that FCR were not affected among the birds fed pre-press solvent-extracted CSM with 8,9 or $10 \mathrm{~g} / \mathrm{kg}$ digestible lysine (Mushtaq et al., 2009). Based on the BWG and FI for the total feeding period, our findings suggest that replacement of SBM by $8 \%$ FCSM resulted in optimum growth performance.

During the fermentation process, phytate $\mathrm{P}$ in the plantsource protein may degrade into inorganic P (Ilyas et al., 1995), whereby the concentration of serum total $P$ may increase in broilers fed fermented SBM (Feng et al., 2007a) and in ducks fed fermented rapeseed meal (Xu et al., 2011). However, no significant changes were detected in serum $\mathrm{P}$ and $\mathrm{Ca}$ in this study, which may associate with the different species of birds and microbes used.

Notably, a part of the nutrients will be diverted from growth for the development of immune cells in broilers. In the current study, broilers fed $4 \%$ and $8 \%$ FCSM had a significant increase in IgM at 21 days of age compared with the birds fed SBM. A significant higher IgM and IgG was also observed in birds fed $8 \%$ FCSM compared with the control from d 22 to 42 . Previous studies indicated that the fermentation can increase the content of small-size peptides, which may improve the immune function of animals (Feng et al., 2007b; Chen et al., 2010). Wang et al. (2003) stated that piglets increased the concentration of immunoglobulin by adding $3 \mathrm{~g} / \mathrm{kg}$ small peptides in the basal diets. Gao et al. (2010) isolated anti-oxidant peptides from cottonseed protein hydrolysates which may improve the immune function as well. Thus, the increase in level of serum IgM and $\operatorname{IgG}$ may be attributed to small peptides formed during the fermentation process (Feng et al., 2007a). On the other hand, the live microbes in the FCSM may also act as probiotics to enhance the broiler humoral immune response 
(Paton et al., 2006). Interestingly, in the present study, the level of $\operatorname{IgA}$ in serum was not affected, which disagrees with the result of Feng et al. (2007a) who found significant level of $\operatorname{IgA}$ in serum of broilers fed fermented SBM. It suggests that there may be other possible mechanism to explain.

The complement system is recognized as a major component of the innate immune system, displaying a wide rage of functions in inflammatory reactions such as destruction of target microorganisms (Morgan et al., 2005). Complement $\mathrm{C} 3$ and $\mathrm{C} 4$ play an important role in activating the complement system through tagging the foreign molecules using their internal thioester bond reacts with nearby hydroxyl or amino groups to form a covalent bond (Dodds and Law, 1998). In the current study, supplement of $8 \%$ FCSM could raise the serum $\mathrm{C} 3$ and $\mathrm{C} 4$ levels in broilers, suggesting that appropriate levels of FCSM may improve the immune function in certain content. However, no comparisons with other studies could be made because there have few reports conducted to evaluate the effects of FCSM on serum complements to date and there is no clear explanation for this effect. Further investigations related to the molecular mechanism to evaluate this effect should be required.

Measurement of immune organ weights is a common method for evaluation of immune status in broilers (Heckert et al., 2002). Ao et al. (2011) demonstrated that birds fed diet containing fermented ingredients could influence the immune organ weights. Apart from the increased immunoglobulins and complements discussed above, findings of the current study showed that there was no significant change in relative weight of spleen, thymus and bursa of fabricius throughout the assay. Similarly, Henry et al. (2001) demonstrated that no significant effect on the liver, spleen and heart weight was noted when 20\% CSM added in poultry diet. A possible explanation for the discrepancy between the results of immunoglubulins and immune organ weights might be the factors including overall farm hygiene and environmental stress. Another factor can not be rule out is the content of free gossypol in feed, for the current study did not use any CSM control diet in the treatments, it was not sure if it plays a role in immune functions.

Taking together, solid-state fermentation with B. subtilis BJ-1 significantly reduced the free gossypol content and improved the quality of CSM. As a result, broilers fed FCSM had similar growth performance to the birds fed SBM by up to $12 \%$. The results of the current experiment also suggested that appropriate replacement of SBM with FCSM could improve growth performance, humoral immune responses and serum complement levels in broilers. Therefore, FCSM may be a promising alternative protein source.

\section{ACKNOWLEDGEMENTS}

This study was supported by the Key Science Project Award of Zhejiang Province Science and Technology Committee (2006C120971 and 2011C12010) and Special Fund Project for Technology Innovation of Hangzhou (20092112A41) of the PR China. Thanks are due to all involved workers.

\section{REFERENCES}

Ao, X., T. X. Zhou, H. J. Kim, S. M. Hong and I. H. Kim. 2011. Influence of fermented red ginseng extract on broilers and laying hens. Asian-Aust. J. Anim. Sci. 24:993-1000.

AOAC. 1999. Official methods of analysis. 16th ed. Association of Official Analytical Chemists, Washington, DC, USA.

AOCS. 2009. Official methods and recommended practices of the AOCS. 6th ed. American Oil Chemists Society, Chicago, IL, USA.

Amartey, S. A., P. C. J. Leung, N. Baghaei-Yazdi, D. J. Leak and B. S. Hartley. 1999. Fermentation of a wheat straw acid hydrolysate by Bacillus stearothermophilus T-13 in continuous culture with partial cell recycle. Process Biochem. 34:289-294.

Azman, M. A. and M. Yilmaz. 2005. The growth performance of broiler chicks fed with diets containing cottonseed meal supplemented with lysine. Rev. Med. Vet. 156:104-106.

Chen, C. C., Y. C. Shih, P. W. S. Chiou and B. Yu. 2010. Evaluating nutritional quality of single stage- and two stagefermented soyben meal. Asian-Aust. J. Anim. Sci. 23:598-606.

Chen, K. L., W. L. Kho, S. H. You, R. H. Yeu, S. W. Tang and C. W. Hsieh. 2009. Effects of Bacillus subtilis var. natto and Saccharomyces cerevisiae mixed fermented feed on the enhanced growth performance of broilers. Poult. Sci. 88:309315.

Chiang, G., W. Q. Lu, X. S. Piao, J. K. Hu, L. M. Gong and P. A. Thacker. 2010. Effects of feeding solid-state fermented rapeseed meal on performance, nutrent digestibility, intestinal ecology and intestinal morphology of broiler chickens. AsianAust. J. Anim. Sci. 23:263-271.

Dodds, A. W. and S. Law. 1998. The phylogeny and evolution of the thioester bond-containing proteins $\mathrm{C} 3, \mathrm{C} 4$ and a2macroglobulin. Immunol. Rev. 166:15-26.

Feng, J., X. Liu, Z. R. Xu, Y. Y. Liu and Y. P. Lu. 2007a. Effects of Aspergillus oryzae 3.042 fermented soybean meal on growth performance and plasma biochemical parameters in broilers. Anim. Feed Sci. Technol. 134:235-242.

Feng, J., X. Liu, Z. R. Xu, Y. P. Lu and Y. Y. Liu. 2007b. Effect of fermented soybean meal on intestinal morphology and digestive enzyme activities in weaned piglets. Dig. Dis. Sci. 52:1845-1850.

Feng, J., W. Q. Ma, H. H. Niu, X. M. Wu, Y. Wang and J. Feng. 2009. Effects of zinc glycine chelate on growth hematological, and immunological characteristics in broilers. Biol. Trace Elem. Res. 133:203-211.

Fritts, C. A., J. H. Kersey, M. A. Motl, E. C. Kroger, F. Yan, J. Si, Q. Jiang, M. M. Campos, A. L. Waldroup and P. W. Waldroup. 2000. Bacillus Subtilis C-3102 (Calsporin) improves live performance and microbiological status of broiler chickes. J. 
Appl. Poult. Res. 9:149-155.

Gamboa, D. A., M. C. Calhoun, S. W. Kuhlmann, A. U. Haq and C. A. Bailey. 2001. Use of expander cottonseed meal in broiler diets formulated on a digestible amino acid basis. Poult. Sci. 80:789-794.

Gao, D., Y. Cao and H. Li. 2010. Antioxidant activity of peptide fractions derived from cottonseed protein hydrolysate. J. Sci. Food Agric. 90:1855-1860.

Gessesse, A. and G. Mamo. 1999. High-level xylanase production by an alkaliphilic Bacillus sp. by using solid-state fermentation. Enzyme Microb. Technol. 25:68-72.

Grigorova, R. and J. R. Norris. 1990. Methods in microbiology, Volume 22: Techiques in Microbial Ecology. Academic Press, New York, New York.

Heckert, R. A., I. Estevez, E. Russek-Cohen and R. Pettit-Riley. 2002. Effects of density and perch availability on the immune status of broilers. Poult. Sci. 81:451-457.

Henry, M. H., G. M. Pesti and T. P. Brown. 2001. Pathology and histopathology of gossypol toxicity in broiler chicks. Avian Dis. 45:598-604.

Henry, M. H., G. M. Pesti, R. Bakalli, J. Lee, R. T. Toledo, R. R. Eitenmiller and R. D. Phillips. 2001. The performance of broiler chicks fed diets containing extruded cottonseed meal supplemented with lysine. Poult. Sci. 80:762-768.

Hermes, I. H., N. R. Asker, M. T. Shulkamy and M. El Sherskl. 1983. The effect of using different levels of decorticated cottonseed meal on performance of chicks: I. Growth and feed efficiency of starting chicks. Ann. Agric. Sci. Ain Shams University, Egypt. 28:1415-1428.

Mountzouris, K. C., P. Tsitrsikos, I. Palamidi, A. Arvaniti, M. Mohnl, G. Schatzmayr and K. Fegeros. 2010. Effects of probiotic inclusion levles in broiler nutrition on growth performance, nutrient digestibility, plasma immunolobulins, and cecal microflora composition. Poult. Sci. 89:58-67.

Morgan, B. P., K. J. Marchbank, M. P. Longhi, C. L. Harris and A. M. Gallimore. 2005. Complement: central to innate immunity and bridging to adaptive responses. Immunol. Lett. 97:171-179.

Ilyas, A., M. Hirabayashi, T. Matsui, H. Yano, T. Kikushima, M. Takebe and K. Hayakawa. 1995. The note on the removal of phytic acid in soybean meal using Aspergillus usamii. AsianAust. J. Anim. Sci. 8:135-138.

Kim, B. N., J. L. Yang and Y. S. Song. 1999. Physiological functions of chongkukjang. Food Ind. Nutr. 4:40-46.

Kim, H. W., E. J. Ko, S. D. Ha, K. B. Song, S. K. Park, D. H. Chung, K. S. Youn and D. H. Bae. 2005. Physical, mechanical, and antimicrobial properties of edible film produced from defatted soybean meal fermented by Bacillus subtilis. J. Microbiol. Biotechnol. 15:815-822.

Mushtaq, T., M. Sarwar, G. Ahmad, M. A. Mirza, T. Ahmad, M. Athar, M. M. H. Mushtaq and U. Noreen. 2009. Influence of pre-press solvent-extracted cottonseed meal supplemented with exogenous enzyme and digestible lysine on performance, digestibility, carcass and immunity responses of broiler chickens. J. Anim. Physiol. Anim. Nutr. 93:253-262.

NRC. 1994. Nutrient requirements of poultry. 9th rev. ed. National Academy Press, Washington, DC, USA.
Paton, A. W., R. Morona and J. C. Paton. 2006. Designer probiotics for prevention of enteric infections. Nat. Rev. Microbiol. 4:193-200.

SAS Institute. 1998. SAS/STAT user's guide: Statistics. Version 7.0. SAS Institute Inc., Cary, NC.

Sterling, K. G., E. F. Costa, M. H. Henry, G. M. Pesti and R. I. Bakalli. 2002. Responses of broiler chickens to cottonseedand soybean meal-based diets at several protein levels. Poult. Sci. 81:217-226.

Terlabie, N. N., E. Sakyi-Dawson and W. K. Amoa-Awua. 2006. The comparative ability of four isolates of Bacillus subtilis to ferment soybeans into dawadawa. Int. J. Food Microbiol. 106:145-152.

Wang, T., Y. M. Fu, J. L. Lv, H. S. Jiang, Y. P. Li, C. Y. Chen and C. M. Zuo. 2003. Effects of mini-peptides on the growth performance and the development of small intestines in weaning piglets. Anim. Husbandry Vet. Med. 35:4-8.

Wang, J. F., Y. H. Zhu and D. F. Li. 2004. In vitro fermentation of various fiber and starch sources by pig fecal inocula. J. Anim. Sci. 82:2615-2622.

Watkins, S. E., J. T. Skinner, M. H. Adams and P. W. Waldroup. 1993. An evaluation of low-gossypol cottonseed meal in diets for broiler chickens: 1. Effect of cottonseed meal level and lysine supplementation. J. Appl. Poult. Res. 2:221-226.

Watkins, S. E., J. T. Skinner, M. H. Adams and P. W. Waldroup. 1994. An evaluation of low-gossypol cottonseed meal in diets for broiler chickens: 2 . Influence of assigned metabolizable energy values and supplementation with essential amino acids on performance. J. Appl. Poult. Res. 3:7-16.

Watkins, S. E. and P. W. Waldroup. 1995. Utilization of high protein cottonseed meal in broiler dites. J. Appl. Poult. Res. 4:310-318.

Weng, X. Y. and J. Y. Sun. 2006. Biodegradation of free gossypol by a new strain of Candida tropicalis under solid state fermentation: Effects of fermentation parameters. Process Biochem. 41:1663-1668.

Xu, F. Z., L. M. Li, J. P. Xu, K. Qian, Z. D. Zhang and Z. Y. Liang. 2011. Effects of fermented rapeseed meal on growth performance and serum parameters in ducks. Asian-Aust. J. Anim. Sci. 24:678-684.

Yu, F., W. C. McNabb, T. N. Barry and P. J. Moughan. 1996. Effect of heat treatment upon the chemical composition of cottonseed meal and upon the reactivity of cottonseed condensed tannins. J. Sci. Food Agric. 72:263-272.

Zhang, W. J., J. Y. Sun and X. Yang. 2006a. Effect of selected fungi on the reduction of gossypol levels and nutritional value during solid substrate fermentation of cottonseed meal. J. Zhejiang Univ. Sci. B. 7:690-695.

Zhang, W. J., Z. R. Xu, J. Y. Sun and X. Yang. 2006b. A study on the reduction of gossypol levels by mixed culture solid substrate fermentation of cottonseed meal. Asian-Aust. J. Anim. Sci. 19:1314-1321.

Zhang, W. J., Z. R. Xu, S. H. Zhao, J. Y. Sun and X. Yang. 2007. Development of a microbial fermentation process for detoxification of gossypol in cottonseed meal. Anim. Feed Sci. Technol. 135:176-186. 